\title{
The Substrate and Urban Transformation. Rome: The Formative Process of the Pompeo Theater Area
}

\author{
* Ph.D. Candidate CRISTIAN SAMMARCO \\ 'Architecture and Project Department, Faculty of Architecture, La Sapienza University, Italy \\ E mail: cristian_sammarco@virgilio.it
}

\begin{tabular}{|l|}
\hline A R T I C L E I N F O: \\
\hline Article history: \\
Received 09 January 2018 \\
Accepted 09 February 2018 \\
Available online 02 September \\
2018 \\
Keywords: \\
Urban morphology; \\
Rome, historical cities; \\
Urban organism; \\
Substratum.
\end{tabular}

This work is licensed under a Creative Commons Attribution - NonCommercial - NoDerivs 4.0.

"CC-BY-NC-ND"

\section{ARTICLE INFO:}

Article history:

Accepted 09 February 2018

Available online 02 September

Keywords:

Rome, historical cities; Urban organism;

\begin{abstract}
A B S T R A C T
The city is an organism that has been transformed through continuous modifications of its form. In these transformations, we can find traces that remain and organize the successive urban aggregates over time. The case that will be proposed is the one of the urban fabric formed in the area of Pompeo's theater, in the Renaissance district of Rome. Through Saverio Muratori's studies on the urban history of Rome and the new archaeological discoveries, the formation of residential building on the remains of the ancient building until its specialization was analyzed. The role of the substratum, evident in this case, the study shows how spontaneous architecture attests to the great forms of the past, and reuses them in every era, transforming and reinterpreting them. In this way the city is so eternal reuse of its forms, its paths and its materials.
\end{abstract}

JOURNAL OF CONTEMPORARY URBAN AFFAIRS (2019), 3(2), 1-7. https://doi.org/10.25034/ijcua.2018.4695

www.ijcua.com

Copyright (c) 2018 Journal Of Contemporary Urban Affairs. All rights reserved.

\section{Introduction}

The research focuses on the study of the historical city and its evolutionary and formative processes through the act of transformation of the existing. Starting from the assumption that "the single work has meaning only if generated and read in the great flow of the cities's transformations and territory, as an ongoing energy that modifies the pre-existing" shows how the formal and constructive characteristics of an ancient organism remain in organization of the city and help in the hierarchization of the elements. According to Saverio Muratori it's possible to find, through the reading of historical textiles, two large organic categories of shapes: the elementary forms, modular and rhythmic, and the accentuating and cohesive forms. The first are characterized by residential construction that specializes in the base cell through a work of addition, recast and synthesis, transforming itself into a supportive organism and

\footnotetext{
*Corresponding Author:

Architecture and Project Department, Faculty of

Architecture, "La Sapienza" University. Italy

Email address: cristian_sammarco@virgilio.it
} 
transmitting this process cyclically to the subsequent building organisms. The latter, object of the study, are represented by the ancient public monumental buildings such as theaters and amphitheatres. These in urban history appear as catalysing elements of paths and building fabrics; they present themselves as the pivot of urban transformation from the late ancient age to the medieval, arriving to our days more or less explicit and legible in urban plots depending on their politicaleconomic role and their characteristics cohesive with the context.

Here we don't want to propose a philological reconstruction of the original ancient building but through an analysis of the sources and reliefs available to us in the archaeological field we want to show the concrete persistence of their shape and the permanence of the physical elements of the structure. We want to show how the ancient substratum is a guiding element that can perimeter our choices within the urban organism so as not to get lost in the sea of possibilism.

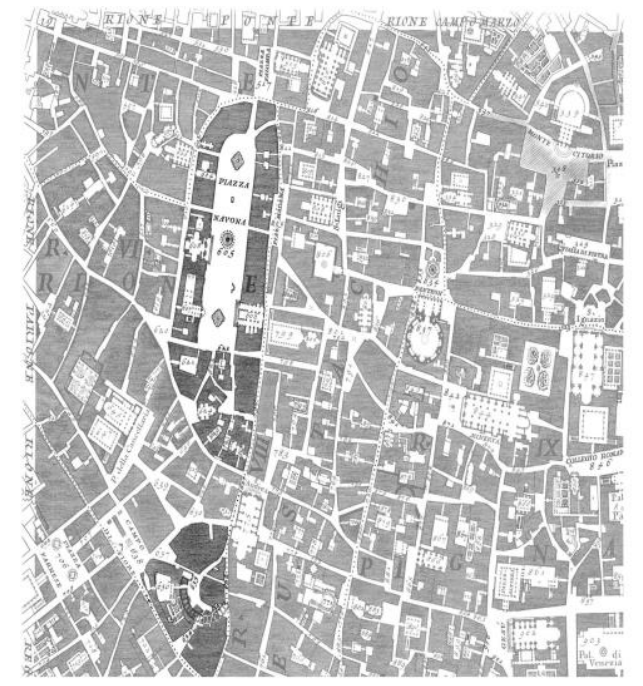

Figure 1. From the plan of (Nolli, 1748) it is evident the permanence of the shape of the ancient buildings in the modern city and their relationship with the paths

\section{The role of the Substrate and the Renaissance district in Rome}

To understand the "formative" character of the sub-stratum in the events of the urban organism it's possible to start from a statement by Luigi Pareyson: "Art could never arise if the whole spiritual life didn't already prepare it with its common format. This is why art has to be sought in a sphere in which that format is able to acquire a determined and distinct character, with its own specific and irrepressible autonomy (Estetica, 2002). "The Roman Southern "Campo Marzio", now called as the Renaissance district, is a virtuous example, in many cases an unicum, of a special antique fabric that hasn't lost its organic character overtime, and of the Roman building events, thanks to the presence of monumental buildings that have maintained "an irrepressible autonomy" through their circular shapes. The area was urbanized in late Republican age under Pompeo Magno, after a long reclamation work due to the continuous flooding of the Tiber that had transformed the site into a marshland, Palus Caprae. The Roman general began the monumentalization of the area in $55 \mathrm{BC}$, probably driven by the desire to exploit and monetize his possessions in the area, with the construction of the theater which then took its name. Numerous monumental complexes followed throughout the imperial age, giving rise to a special building district for play and religious purposes. Among these complexes are important for this study, in addition to the theater of Pompeo, the stadium of Domitiano and his Odeon, the theater of Balbo, that of Marcello and the quadriportici present in the area. These were connected, through a tangible relationship to a series of paths that are still partly recognizable in the current topography.

The transition between late ancient and middle ages, very often obscure and neglected in urban morphology studies due to the difficulty of the information available, is instead fundamental to understand how this fabric of special buildings has continued to live through the conservation of its plant. Marcello Marocco and Luigia Zoli, in a critical paper ${ }^{1}$ on the morphology of the Renaissance district, show the factors that have contributed to the formation and modification of this urban sector. They articulate the study in five essential points:

1) reconfirms the elements such as walls, bridges, streets and monuments that characterized the ancient structure;

2) presence of catalyst elements of successive building transformations such as basilicas, villas, hortus and domus cultae;

3) creation of a system of tensions capable of guiding the reconstitution of urban morphology according to certain directions;

4) the great polarities (centers of life): Campidoglio, Mausoleum of Hadrian (later Castel Sant'Angelo) and the Vatican;

5) the type of land use that in the Middle Ages gravitates around the residential nuclei that are both secular and religious; 
Through these categories it's possible to summarize the transition from the ancient monumental city to the medieval one in the bend of the Tiber, which takes place through continuous interstitial developments responding to a need for continuity of the urban jersey. Unlike the other medieval centers that gravitated around an original nucleus where political and religious powers resided. Rome has no real center on which to gravitate and this has involved an isotropic character of the urban tissues, a strong resistance to change. This isotropy, however, is due to the area of the Western and Southern Campo Marzio in the presence of large monumental structures that possess the original quality of organically linking the transformations into a single resistant organism, formally autonomous, but participating in the continuity of the medieval and then modern city. Also Morocco-Zoli state: "The intrinsic relationship that binds the new city to the old one, through the use of ruins as a substratum, is a structural law that conditions the development of the city already in the Middle Ages. This phenomenon is due to the permanence, in the new organism, of certain grandiose cuts, such as the emptiness of Piazza Navona and the long straight via del Corso."

The special ancient building enters the formative dynamics of the medieval city by welcoming the prerogative of its plant in commercial and residential base cells that, through the phenomenon of recast, specialize again. A continuous life cycle characterizes this part of the Campo Marzio and the circular plant buildings of the Mediterranean area; it's the physical and not just typological reuse of the existing key for these stratified tissues. Gian Luigi and Mattia Maffei (2011), continuing the research of Gianfranco Caniggia on basic construction, face the reading of the special building in which they assert that the inverse relationship, or the de-specialization treated here, must be studied on the reverse: "What it was an internal path - the horizontal distribution - reacquires the value of a real external path that is, of the road - as well as the elementary aggregated cells, in a serial or non-serial way, summarize the typological role they had in basic construction (Maffei, 2011 )".

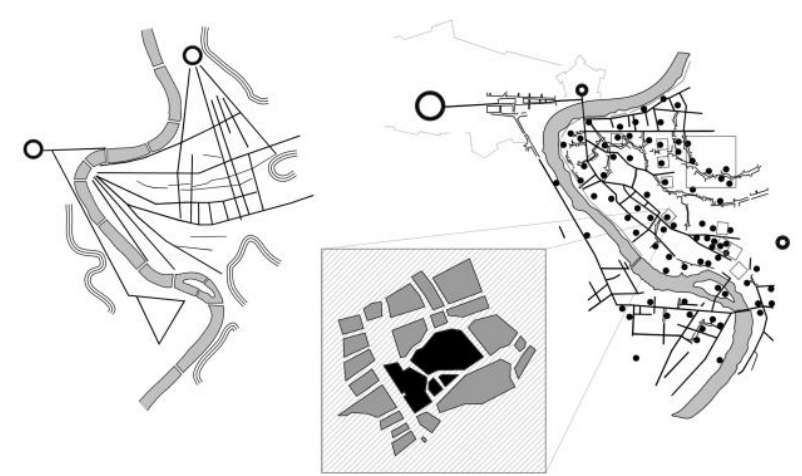

Figure 2. In the first scheme we can see how the polarities of the Vatican and Piazza del Popolo influenced the orientation of the routes.In the second scheme we can see how the Roman routes, in black, persist and orient the medieval fabric of the city. The medieval paths are grafted onto the ancient ones and they grant the new churches, schematized in circles, with the ancient traces. The Roman monumental complexes, black squares, become catalysing elements of the new religious buildings. In the zoom the study area is synthesized through a schematization of the Bufalini's map; 1551.

\section{The Pompey theater and the factors of permanence}

In the study of a fabric deriving from an ancient substratum, it is necessary to make use of the contribution of the archaeologists for the survey of the existing remains, their identification in the current organism and the reconstruction of the original artefact. The case study of the monumental area of the theater of Pompeo becomes emblematic in the identification and reading of the phases of the training process. From this derives the modern fabric between Piazza Campo de 'Fiori and Largo di Torre Argentina. The shape of the theater is now perfectly recognizable both planimetrically and along its outer perimeter along the Via dei Chiavari (which partly occupies the ancient scene), the streets of Paradiso, the Biscione and the Via dei Giubbonari up to Piazza Campo de ' Flowers. Its shape is even more evident along the Grottapinta road that follows the internal curve of the cavea. Thus we identify the factors of permanence that induce the reading to start from the most obvious parameter: the city of today. The study of urban morphology is a backward operation in time; we do not start from the ancient topography but we must read the fabric like a text leafing through it layer by layer. 


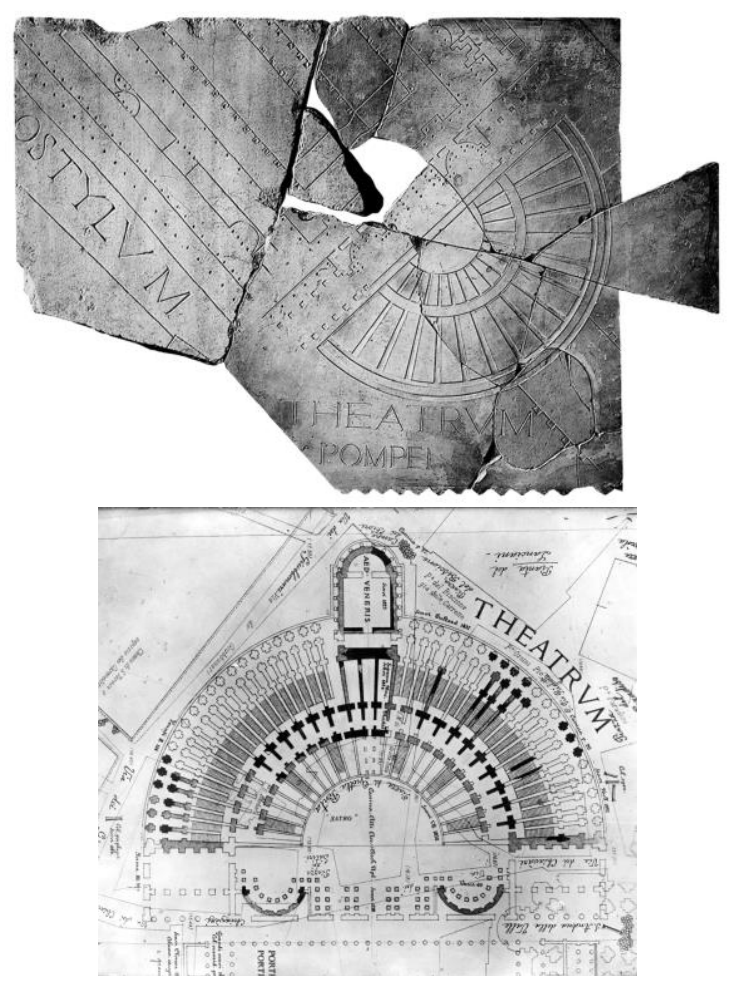

Figures 3 - 4. The Forma Urbis gives us only an approximation of the form of the theater of Pompey. The Victorious Venus temple does not appear in the drawing. In the relief and plan of the Lanciani, the presence and permanence of the temple in the block appears evident.

Among the key themes of the study there is the question of fruition: in these buildings for the purpose of play, usability evolves according to historical epochs, always restoring new meanings to the forms in a continuous process of organic renewal; biological. A generation of enlightened archaeologists, attentive to this theme of urban morphology, is that of the '70s represented by Anna Maria Capoferro Cencetti (1979), who in his essay "Variations in the time of the functional identity of a monument: the theater of Pompeo" reminds us the importance of matter / material through the names given to this theater by atky writers: lapideum and marmoreum. Theatrum lapideum and marmoreum because it was the first stable theater in masonry of Rome, then called magnum because despite the rise of nearby theaters it remained the theater par excellence of Rome where the most important events were to be held. The history of theater and of the Roman and Hellenic theatrical stage typology has long been consolidated in both the archaeological and architectural academic environment, but it is important to remember the news for which, given the prohibition to build a masonry building Rome availed itself of the construction of a temple dedicated to the victorious Venus in axis with the cavea; this expedient justified the presence of the steps as a great staircase of access to the temple used for the celebrations of the cult.

The news on the theater inform us that this was restored numerous times up to 510 AD. By Septimius Severus and in use until the eighth century.

\section{The Middle Ages and the formative process}

When the oral tradition took the place of the written one, the places were equivocated and the new points of reference of the topography replaced the old ones. Ancient Rome entered the dimension of the fantastic and was transformed into itself; only toponymy in many cases allowed the memory and transmissibility of places and its artifacts. In the Einsiedeln itinerary of the second half of the 8th century, mention is made of both the Theatrum of Pompeo in its monumental structure and other buildings in the area within the pilgrim route. It is not possible to know the exact moment when there was the first de-specialization of the complex and the occupation of the ruins with the settlement of the type of the terraced house. Surely we can imagine the occupation from the ninth century of its arches by protohousing and commercial units: the crypates. This spontaneous occupation of the great Roman structures justifies the passage of the population of the population from over 1 million inhabitants to less than 20,000 and the consequent abandonment of linear and modular residential fabrics in favor of cohesive structures that allowed, besides a structural solidarity, also a use in terms of defense of the territory ${ }^{2}$ exploiting, as in the case of the Domitian stadium, the interior of the structure as a pertinent area dedicated to cultivation. Maffei makes explicit this process linking it to the overturning of the paths and the maximization of the use of space: "The theater of Pompeo in Rome regains as an external path, in addition to the one around it, the internal one of the" fauces ", between cavea and scene, and it doubles with the formation of an intermediate fabric, in the place of the orchestra, thus obtaining a double front in the use of the cavea. Another example is the structuring of the sixteenth-century Piazza Navona, also in Rome, which takes the place of the free space inside the stadium of Domitian. This area was previously used as a part of the medieval terraced houses that had been located in the modular perimeter structures of the stadium, transforming the bays

\footnotetext{
2 . The medieval turreted rome will then be focused on a constellation of residential and defensive housing aggregates arising on the major arteries of city traffic. The most common example is the fortress of the Pierleoni, then Palazzo Savelli and Orsini on the ruins of the theater of Marcello.
} 
of the ancient arches. An equal transformation undergoes the more contained amphitheater of Lucca, while in Florence the internal area of the amphitheater is built with the introduction of two restructuring paths that crosswise cut the original special building ". An important factor for the reconstruction of the training process is the presence of the sacred buildings in this area. In 1186, in the Bull of Urban III, the small church of Santa Maria in Cripta Pincta is already mentioned and probably takes its name from the paintings in the cryptae of the theater of Pompeo. Even more ancient is the church of Santa Barbara (X - XI century) ${ }^{3}$ and its dating at this time is possible thanks to an epigraph of the period on the wall to the left of the entrance 4 . This church shows the characteristics of adaptation of the artefact to the ancient structures: in a plan of 1601 we can see how the ancient plan of the church followed the wedges of the amphitheater, while in another of 16775 it was possible to reconstruct the role of via di Grottapinta as a master path due to the presence of a staircase that marked the original entrance to the building from the old cavea.

In the Mirabilia the area of the theater of Pompeo is identified with the term Templum probably because the part best preserved and still perceptible in its original form had to be that of the Temple of Venus Vincitrice that will be recurring element and urban land-mark in the history of this part of the fabric and that recurs with different names in the Orsini Archive documents. The history of the Orsini property is partly the history of the theater of Pompeo and through the writings it is possible to reconstruct it synthetically: in 1150 the first nucleus of the stronghold with the transfer of Trullum, between 1242 and 1268 the Orsini bought from their relatives of Monte Giordano all rights to the Arpacasa that can be identified with the temple of Venus. In fact, there is talk of a Camera Magnab, probably the temple cell reused and transformed into a tower to defend the fortress built through the recast of the purchased particles. Between 1290 and 1296 the Orsini bought other portions of the area, and other residential and commercial

3 Some authors date it also to the Constantinian age but it is to be excluded because the last restorations of the theater turn out to be of the VI century.

4 In this epigraph reads the renunciation of all rights by Giovanni di Roizo and his wife on the pertinences of the building and on the church itself. We can imagine that among the appurtenances there were parts of the theater for residential and commercial use that were rented or used as marble quarries.

5 Archive of the Vicariate of Rome, Compagnia dei Librai, tome 43, pag. 133.

6. We speak of the Arpa house and of a Camera Magna in the testament of Matteo Orso Orsini of 1279. The Camera Magna is identifiable with the cell of the temple. properties both on Via dei Giubbonari, adjacent to Santa Barbara. With the purchase of properties between Via di Grottapinta, Piazza dei Satiri, Via dei Giubbonari, Piazza Campo de 'Fiori and the Biscione, the layout of the area is definitively configured. This fact was of primary importance for the family as it was possible to control the Valeria street, one of the main accesses for southern Italy and the Kingdom of Naples. This strategy of occupation and fortification was implemented by all the great Roman families in the strategic points of the city. The theater of Marcello transformed into a fortress was in fact a point of control of the passage of goods and pilgrims between the two banks of the Tiber.

The perimeter of the fabric that arose between the structures of the Roman monument offers us an important example of the phenomenon of the sliding of the front. This phenomenon, common to many urban fabrics arising, or not, from a substratum material, derives from the presence of an impassable limit: the perimental walls of Palazzo Orsini. On the front, between the Campo de 'Fiori and Via dei Giubbonari, new base cells were set up, destined to the shop until a fifth street was redefined on the new present route. Not being able to grow in height the monocells multiplied horizontally approaching each other until saturating the space redefining a new limit.

Between the 14th and 15th centuries, the two blocks stand in the orchestra area, while in 1634 a fire burned three shops near the church of Santa Barbara7; this event allowed the redefinition of the space that was transformed into a square that elegantly follows the orientation of the rays of the ancient theater.

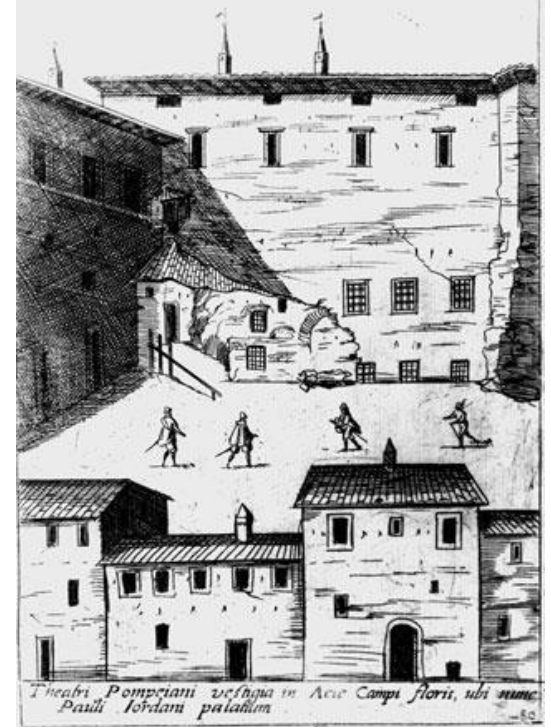

Figure 5. In this drawing by Giuseppe Maggi of 1615 we can see how the Orsini palace area appeared and how

7. The news of the fire "nella strada de'Gipponari "is handed down to us by the Diario del Gigli, 1660-1672. 
the building was born from the ancient substratum. The Roman remains of the arches on the ground floor are evident.

\section{Survey methodology for a substrate architecture}

Capoferro Cencetti (1979) offers us a threepoint verification for the study of the transformations and the recognizability of these urban catalyst elements. This survey methodology is an excellent starting point for the study of today's historical centers because it allows to perimeter the field of research; the points proposed by the scholar are:

1) the recognition of visible findings;

2) structural relief and identification of evolutionary processes through iconographic and archival documentation;

3) the analysis of the existing relationship between form, structural subdivision and use;

The first point is to support urban morphology to concretely materialize the research carried out. These are tangible proofs of the transformation of the architectural organism. In the case study of the theater of Pompeo, the reconnaissance of visible artifacts is documented by Colini, 1937, but it is now possible to make use of further surveys published in $2013^{8}$ showing the findings on the cadastral parcels of via del Biscione 78, Piazza del Paradiso 67 - 69 and piazza del Pallaro $10-11$. From the reliefs the reuse of the ancient walls is evident both as the foundation of the successive edificazioni, and as vertical structural elements.

The second point proposed is the survey of the blocks in order to reconstruct the training process and its phases. The Muratorian relief of the ground floors, even if with some approximations, has provided us with the demonstration of how the archaeological substratum has conditioned the fabric not only at the level of the lower floors but also at the upper levels as evidenced by the study of the Orsini palace floor plans.

The third point tries to overcome the merely technical and constructive aspect, whose highlight risks debasing the real meaning of the monument by tracing it back to what it once represented and relegating it to a symbol of a precise period. We must consider the actual relationship between the community and the architectural themes that express this same idea of community. Its shape has allowed it not to undergo variations over time such as to mark its decline and its end. Circular, elliptic and, more generally, shapes characterized by an external curve-like and closed surface with convergent rays in one or two internal points, are more opposed to variations and accretions than others. In addition to the wraparound shape, the modular structure of the wedges is important. The pitch of the arches is such that it can be exploited for the settlement of terraced houses and with the overturning of the modules it is possible to saturate the various wedges. However, if the theater of Pompeo welcomes a basic building fabric, albeit with different variations, this does not happen in the palace specialization: the Orsini building can not develop in harmony with the new demands of the Roman Renaissance palace. The building is strongly asymmetrical and totally different from its contemporaries and a commentator of the time describes it as a negative tone stating that it has a malfatta lodge and the outer walls try to take "façade form" but without success. Undoubtedly this problem is due not only to the shape of the ancient substratum but also to the lack of a figure that could interpret this process; what instead happened magnificently in Palazzo Massimo at the columns.

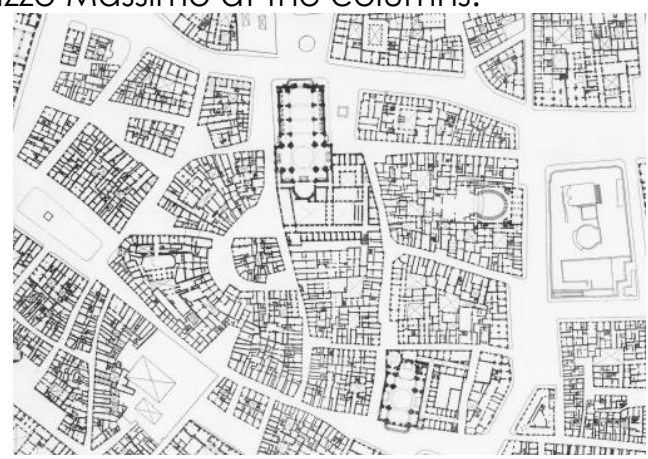

Figure 6. In the reliefs of the ground floors of the area it is possible to see how the walls and the spaces are conditioned by the Roman structure. The substratum is evident and conditions the successive transformations.

\section{Conclusions}

We must not dwell on the monument as an object but also in the contemporary era understand the evolutionary and formative process. This allows us to face the problems of our historical centers not only in terms of conservation of the existing but above all to imagine a continuation of this process that can lead to a further transformation of the existing. Historical textiles can emerge from monumentalization in order to return to participate in the transformation of the city without being crystallized in a single historical period. In every phase of the evolution of the city are in fact contained all those past but also the image of those that will be in the future. 


\section{Acknowledgements}

This research did not receive any specific grant from funding agencies in the public, commercial, or not-for-profit sectors.

\section{Conflict of interests}

The author declares no conflict of interest.

\section{References}

Frutaz, A. P. (1962). Le piante di Roma[The plants of Rome], 3 voll., Istituto di Studi Romani, Roma. https://www.tandfonline.com/doi/abs/10.1080/00 043079.1963.10788735?journalCode=rcab20

Nolli, G. B. (1932). Pianta di Roma del 1748, in Roma di Benedetto XIV. La pianta di Roma di Giambattista Nolli del 1748, riprodotta da una copia vaticana, con introduzione di Francesco Ehrle[Map of Rome from 1748, in Rome by Benedict XIV. The plan of Rome by Giambattista Nolli of 1748, reproduced by a Vatican copy, with an introduction by Francesco Ehrle], Biblioteca Apostolica Vaticana, Città del Vaticano. https://opac.sbn.it/

Bollati, S. Caniggia, G. (1963). Esperienze operative sul tessuto urbano di Roma, Facoltà di Architettura[operational experiences on the urban fabric of Rome, Faculty of Architecture], Università degli studi di Roma, Roma. https://www.google.com/

Borsari, L. (1897). Topografia di Roma antica[Topography of ancient Rome], Ulrico Hoepli Editore, Milano. https://archive.org/details/topografiadirom00bors goog

Caniggia, G. (1976). Strutture dello spazio antropico [Structures of the anthropic space], Firenze. http://www.worldcat.org/title/strutture-dellospazio-antropico-studi-e-note/oclc/3274778

Caniggia, G., Maffei, G. L. (1979). Lettura dell'edilizia di base, Venezia, Marsilio[Reading of basic buildings, Venice, Marsilio] https://inpromcoi.firebaseapp.com/25/Letturadelledilizia-di-base.pdf

Capoferro Cencetti, A. M. (1979). Variazioni nel tempo dellidentita' funzionale di un monumento: il teatro di Pompeo [Variations in time of the functional identity of a monument: the theater of Pompey], https://zenon.dainst.org/Record/000437273

Gregorovius, F. (1902). Storia della città di Roma nel Medioevo, Società Editrice Nazionale [History of the city of Rome in the Middle Ages, National Publishing Company] , 4, Roma; Italy. https://www.ibs.it/storia-della-citta-di-roma-libroferdinand-gregorovius/e/9788806376895

E. Hubert. (1993). (a cura di), Roma nei secoli XIII e XIV [Rome in the thirteenth and fourteenth centuries], Viella. https://www.viella.it/libro/9788885669246

Krautheimer, R. (1981). Profilo di una città, 312 1308[Profile of a city, 312 - 1308], Edizioni dell'Elefante, Roma. http://www.aracneeditrice.it/index.php/pubblicaz ione.html? item=9788871760377

Maffei, G. L. Maffei, M. (2011). Lettura dell'Edilizia Speciale [Reading of Special Construction], ALINEA, https://www.lafeltrinelli.it/libri/maffei-gian-

Ivigi/lettura-edilizia-speciale/9788860556066

Muratori S. et al., (1963). Studi per una operante storia urbana di Roma[Studies for an active urban history of Rome], C.N.R., Roma. https://www.academia.edu/34942497/POR_I_prog etti_urbani_per_Roma_di_Saverio_Muratori.pdf

Paroli L., Delogu, e P. (1993). La storia economica di Roma nell'alto medioevo alla luce dei recenti scavi archeologici [The economic history of Rome in the early Middle Ages in light of recent archaeological excavations], Edizioni Allinsegna del Giglio, Firenze. https://www.insegnadelgiglio.it/

Portoghesi, P. (1971). Roma nel Rinascimento [Rome in the Renaissance] , Electa, Milano. https://www.abebooks.it/ricerca-libro/titolo/romadel-rinascimento/autore/paolo-portoghesi/ .

Strappa, G. (1995). Unità dell'organismo architettonico [Unity of the architectural organism], Dedalo Edizioni, Roma. http://www.giuseppestrappa.it/wpcontent/uploads/201 1/04/StrappaGUnitadellorga nismoarchitettonicoBariDedalo 1995.pdf

Strappa, G. (2014). L'Architettura come Processo: il mondo plastico murario in divenire [Architecture as a Process: the plastic world in progress], Franco Angeli,

Roma. https://www.francoangeli.it/Ricerca/Scheda_libro. aspx? Codice Libro=1098.2.26

Soprintendenza archeologica di Roma, Roma. (2013). Archeologia nel centro, II La "città murata"[ Archeology in the center, II The "walled city], De Luca Editore. https://books.google.com.tr/books/about/Roma_ archeologia_nel_centro_La_citt\%C3\%A0_mu.html? id $=j 3$ YJKAEACAAJ\&redir_esc $=y$

Tomei, P. (1942). L'Architettura a Roma nel Quattrocento[Architecture in Rome in the fifteenth century], Palombi, Roma. https://books.google.com.tr/books/about/L_archit ettura_a_Roma_nel_Quattrocento.htmle id=SRzqA AAAMAAJ\&redir_esc $=y$

Vaccaro, P. (1963). Tessuto e tipo edilizio a Roma dalla dine del XIV secolo alla fine del XVIII secolo[Fabric and building type in Rome from the end of the fourteenth century to the end of the eighteenth century]. Roma: Centro Studi di storia urbanistica.

http://www.giuseppestrappa.it/?p=1517 